\title{
PERANCANGAN SISTEM INFORMASI PROFIL MASJID BERBASIS WEBSITE
}

\author{
Alldy Novryaldy, Tedy Setiadi \\ Program Studi Teknik Informatika \\ Fakultas Teknologi Industri - Universitas Ahmad Dahlan \\ Jl.Prof. Dr. Soepomo, Janturan, Yogyakarta \\ alldy1400018051@webmail.uad.ac.id,tedy.setiadi@tif.uad.ac.id
}

\begin{abstract}
Abstrak
Profil masjid merupakan gambaran menyeluruh tentang karakter suatu masjid. Profil masjid berguna sebagai sumber informasi untuk menentukan langkah dalam upaya memakmurkan masjid. Pengelolaan administrasi merupakan salah satu cara yang dapat dilakukan untuk mendapatkan profil masjid. Pengelolaan administrasi yang terjadi di masjid Kota Yogyakarta belum dilakukan secara maksimal. Hal tersebut menyebabkan pengurus masjid belum memiliki informasi yang cukup dalam menentukan langkah untuk memakmurkan masjid serta belum terdatanya seluruh masjid di Kota Yogyakarta, membuat Kementerian Agama Kota Yogyakarta kesulitan untuk mengetahui profil suatu masjid. Hal ini menyebabkan proses pembinaan masjid menjadi terhambat. Tujuan jurnal ini adalah membangun sistem yang dapat membantu masjid dan Kemenag dalam mengelola administrasi dan menyajikan informasi profil masjid. Metode pengumpulan data yang dilakukan dengan menggunakan metode wawancara, studi literatur dan survei. Tahapan pengembangan sistem menggunakan pendekatan Object Oriented (OO) seperti Use case diagram, Activity diagram dan pengujian (Black box dan Usability). Penelitian yang dilakukan menghasilkan sebuah sistem yang dapat menyajikan informasi profil masjid. Hasil pengujian Black box mendapatkan nilai $100 \%$ dan hasil pengujian usability menggunakan System Usability Scale (SUS) mendapatkan nilai 86,5. Berdasarkan kedua pengujian yang dilakukan, dapat disimpulkan bahwa sistem berjalan sesuai dengan kebutuhan dan diterima pengguna.
\end{abstract}

Kata kunci: Profil Masjid, Administrasi, Sistem, Informasi, Usability

\begin{abstract}
The profile of the mosque is a metaphor that represent about the character of a mosque. The profile of the mosque used as a source of information to determine the steps in efforts to enliven the mosque. The administrative supervision is one of the way that can be done to get a profile of the mosque. The administrative supervision that occurred on the mosque in Yogyakarta has not been done comprehensively. This is causing the mosque officers not have sufficient information yet to determine the further steps. Moreover, the mosques in Yogyakarta not recorded yet entirely that lead ministry of religion in the city of Yogyakarta hard to find out the profile of the mosque. This means that the development process of the mosque will be impeded. The purpose of this journal is building a system that help the mosque officers and ministry of religion in administrate the programs and provides the mosque profile. The methods of compiling data are implemented using the interview, literature study, and survey. The phase of the system development used the approach object oriented (for instance: Use case diagram, activity diagram) and testing (black box and usability) Based on the research that have been conducted, we produce a system that could provides the mosque profile. The result of the Black box test acquired $100 \%$ and the result of usability used System Usability Scale (SUS) acquired $86,5 \%$. Based on the both, we conclude the system as needed and accepted by the user.
\end{abstract}

Key words: Mosque Profile, Administration, System, Information, Usability 


\section{Pendahuluan}

Masjid berasal dari Bahasa arab sajada yang berarti tempat sujud atau menyembah Allah SWT. Fungsi masjid tidak hanya sebagai tempat untuk melaksanakan sholat tetapi juga sebagai sarana pengembangan wawasan keislaman, pusat kegiatan sosial dan pusat pembinaan umat islam. Masjid harus berfungsi dengan baik, sehingga keberadaan masjid dapat memberi manfaat bagi masyarakat sekitarnya. Hal tersebut harus dilakukan dengan manajemen masjid yang baik (Qadaruddin, Nurkidam, \& Firman, 2016).

Profil masjid merupakan gambaran menyeluruh tentang karakter suatu masjid. Profil masjid berguna sebagai sumber informasi untuk menentukan langkah dalam upaya memakmurkan masjid. Pengelolaan administrasi salah satu cara yang dapat dilakukan untuk mendapatkan gambaran mengenai karakter suatu masjid. Beberapa pengelolaan administrasi yang terjadi di masjid seperti, pendataan jamaah, pengelolaan keuangan dan agenda kegiatan.

Pendataan jamaah bertujuan agar masjid memiliki gambaran tentang masyarakat di sekitarnya. Dengan demikian, masjid dapat menggali potensi masyarakatnya, sehingga dapat membentuk pola pembinaan yang efektif dan efisien dalam memakmurkan masjid. Pengurus masjid harus memahami bahwa kemakmuran masjid terletak pada kegiatan pemberdayaannya, sebagai suatu upaya yang harus diikuti dengan tetap memperkuat potensi atau daya yang dimiliki oleh setiap masyarakat (Iwan \& Herdiana, 2018). Salah satu upaya yang harus dilakukan pengurus masjid dalam mengelola dan memakmurkan masjid adalah melalui pelibatan jemaah dan masyarakat dalam berbagai kegiatan masjid. Hal tersebut dilakukan untuk membangkitkan semangat masyarakat dalam memakmurkan masjid. Informasi kagiatan yang akan diselenggarakan harus disampaikan secara merata kepada masyarakat, sehingga informasi tersebut tidak hanya diketahui oleh orang-orang yang sering ke masjid (Suherman, 2012).

Masjid memerlukan biaya yang tidak sedikit dalam operasionalnya. Pengelolaan keuangan masjid harus dilakukan dengan cermat dan tepat, setiap aktifitas keluar masuk keuangan harus tercatat jelas dan terkalkulasi dengan benar. Masjid dituntut untuk mengelola keuangan secara transparan dan akuntabel (Haq \& Dewi, 2013).
Beberapa masalah yang terjadi pada masjid di Kota Yogyakarta adalah masjid belum melakukan pendataan jamaah, masjid tidak memiliki gambaran tentang masyarakat di sekitarnya, sehingga masjid kesulitan untuk menentukan dan melibatkan jamaah dalam setiap agenda kegiatannya. Pengelolaan keuangan masjid masih menggunakan lembar kerja, banyaknya aktifitas keluar masuk keuangan yang terjadi membuat proses mengelola keuangan menjadi sulit dan membutuhkan waktu yang lama. Media yang digunakan untuk menyampaikan informasi kegiatan masjid hanya melalui pengeras suara, papan pengumuman dan grup whatsapp. Media yang digunakan tersebut belum optimal, sehingga informasi tidak tersampikan secara merata kepada masyarakat.

Peran pemerintah juga diperlukan dalam menunjang pembinaan masjid. Seksi Bimbingan Masyarakat ( $\mathrm{Si}$ Bimas) Islam merupakan salah satu unit kerja dari Kementerian Agama (Kemenag) Kota Yogyakarta. Si Bimas Islam bertugas dalam urusan kemasjidan seperti pendataan masjid dan pembinaan masjid yang berada di wilayah kerjanya.

Pendataan masjid dilakukan secara periodik, pendataan yang terjadi pada saat ini telah menggunakan Sistem Informasi Masjid (SIMAS). SIMAS memiliki 4 tipe user yaitu admin pusat, user Provinsi (Kanwil), user Kab/Kota (Kankemenag), dan user KUA (Sub Direktorat Kemasjidan, 2014). Setiap institusi dapat menetapkan seorang pegawai sebagai user pada SIMAS Hal tersebut membuat pegawai menjadi kewalahan dikarenakan banyaknya masjid yang harus didata pada SIMAS. Akibatnya, beberapa masjid tidak terdata, sehingga jumlah masjid yang telah terdapat pada SIMAS tidak mengalami perubahan. Hal tersebut membuat Kemenag kesulitan untuk mengetahui jumlah dan profil masjid yang berada di Kota Yogyakarta dan menyebabkan proses pembinaan masjid menjadi terhambat.

Dari permasalahan yang telah diuraikan, maka dibutuhkan sebuah sistem yang dapat membantu pengurus masjid dan Kemenag dalam pengelolaan administrasi dan menghasilkan informasi profil dari setiap data administrasi yang di kelola. Sistem yang akan dibangun berbasis website dengan menggunakan salah satu bahasa pemrograman website yaitu PHP Hypertext Preprocessor (PHP). Website dipilih karena beberapa kelebihannya seperti dapat di akses dari berbagai devices dan sistem operasi (Muharam, 2018). 


\section{KAJIAN LITERATUR}

\section{II.1 Kajian Terdahulu}

Penelitian ini mengacu pada beberapa penelitian yang pernah dilakukan sebelumnya. Penelitian (Wardana \& Aribowo, 2013) menghasilkan sebuah sistem informasi administrasi yang dapat memproses pengelolaan pendataan jamaah, donatur, arsip, mubaligh dan data keuangan, dan memasukan data serta keluaran berupa laporan. Sistem yang dikembangkan belum memiliki fitur untuk mempublikasikan informasi kegiatan masjid.

Penelitian (Syaifullah, Priyanto, \& Irwansyah, 2016) menghasilkan sebuah sistem yang dapat dijadikan sarana bagi masjid, panti asuhan, dan pesantren untuk membagikan informasi kepada masyarakat kota Singkawang. Sistem yang dikembangkan belum memiliki fitur pengelolaan keuangan dan pendataan jamaah.

Penelitian (Buana, Susanto, \& Suhandiah, 2016) menghasilkan aplikasi untuk memberikan informasi kegiatan kepada jamaah dan pengisi kegiatan dengan menggunakan sms gateway, serta menghasilkan laporan kehadiran peserta dalam setiap kegiatan dan laporan keuangan masjid sehingga dapat membantu pengurus Masjid Tanwir dalam mengevaluasi tingkat kehadiran dalam setiap kegiatan secara berkala. Sistem yang dikembangkan hanya dapat digunakan oleh 1 masjid. Informasi kegiatan yang dihasilkan hanya berasal hanya dari 1 masjid.

Penelitian (Welim \& Sakti, 2016) menghasilkan sistem yang dapat mengelola dana pemasukan dan pengeluaran. Sistem dapat memberikan informasi penerimaan dan pengeluaran dana. Sistem yang dihasilkan hanya berfokus pada pengelolaan keuangan, belum terdapat fitur untuk pendataan jamaah dan publikasi informasi kegiatan masjid.

\section{II.2 Manajemen Masjid}

Terdapat 3 bidang yang harus di kelola oleh Dewan Kemakmuran Masjid (DKM) untuk meningkatkan kinerja pembinaan secara komprehensif, (Iwan \& Herdiana, 2018), diantaranya: bidang manajemen (idarah) untuk meningkatkan kualitas pengorganisasian masjid dengan melihat bagaimana pengelolaan masjid secara professional dan terorganisir, Administrasi merupakan bagian dari pembinaan idarah, beberapa kegiatan administrasi yang harus dilakukan masjid yaitu, pembukuan keuangan masjid, laporan keuangan masjid, pembukuan agenda kegiatan, pencatatan jamaah dan lain sebaginya (Suherman, 2012). Pembinaan bidang kemakmurkan masjid (imarah) dengan melihat bagaimana keberfungsian masjid dalam kegiatan pemberdayaan umat, dan pembinaan bidang pemeliharaan masjid (riayah) dengan melihat bagaimana bentuk fisik dan sarana prasarana masjid yang senantiasa di pelihara dan ditingkatkan dengan baik (Busthomi, 2017).

\section{II.3 Sistem Informasi}

Sistem informasi dapat didefinisikan sebagai serangkaian komponen yang saling berhubungan yang mengumpulkan atau mendapatkan data, memproses, menyimpan dan mendistribusikan informasi untuk mendukung pengambilan keputusan dan pengawasan di dalam sebuah organisasi (Laudon \& Laudon, 2014).

\section{II.4 Pengujian Usability}

System Usability Scale (SUS) adalah salah satu kuisioner yang digunakan untuk pengukuran usability (Pudjoatmodjo \& Wijaya, 2016). SUS terdiri dari 10 pertanyaan dengan menggunakan skala likert 1 sampai 5 (sangat tidak setuju, tidak setuju, ragu-ragu, setuju dan sangat setuju). Pertanyaan nomor ganjil $(1,3,5,7,9)$ merupakan pertanyaan yang bernada positif. Sedangkan pertanyaan nomor genap $(2,4,6,8,10)$ merupakan pertanyaan bernada negatif.

Skor pada pertanyaan ganjil dihitung dengan cara bobot pertanyaan $(x i)$ dikurangi 1 atau $x i-1$. Sedangkan skor untuk pertanyaan genap dihitung dengan cara 5 dikurangi bobot pertanyaan (xi). Skor SUS didapat dengan cara jumlah skor ganjil dan skor genap dikali dengan 2,5 (Ardiansyah \& Ghazali, 2016).

Berdasarkan nilai rata-rata skor SUS dapat diketahui tingkat usability sistem yang dikembangkan. Penilaian berdasarkan 3 kategori yaitu Not Acceptable, Marginal, dan Acceptable. Skala konversi skor SUS ditunjukkan pada Gambar 1.

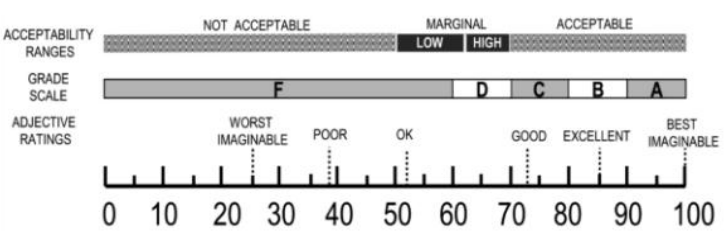

Gambar 1. Skala konversi skor SUS 


\section{Metode Penelitian}

\section{III.1 Tahap pengembangan sistem}

Pengembangan sistem pada penelitian ini menggunakan model Waterfall dengan pendekatan Object Oriented (OO) (Sukamto \& Salahuddin, 2016). Model waterfall dapat dilihat pada Gambar 2.

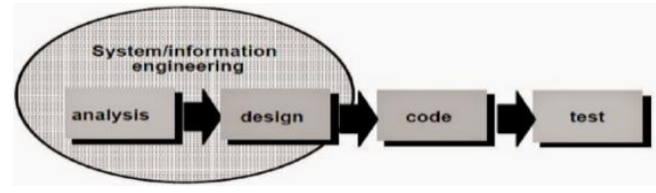

Gambar 2. Metode Waterfall

\section{III.1.1 Analisis Kebutuhan}

Tahap pengumpulan kebutuhan pengguna (pengurus masjid dan Kemenag) terhadap sistem. Kebutuhan tersebut akan didefinisikan sebagai fungsional yang harus dimiliki oleh sistem.

\section{III.1.2 Desain} yaitu :

Desain yang dilakukan dibagi menjadi 3 bagian

1. Desain sistem, dibuat dalam bentuk diagram aktivitas untuk menggambarkan alur kerja fungsional yang akan dimiliki sistem.

2. Desain data, bertujuan untuk menggambarkan pemodelan data dan struktur data yang akan digunakan sistem. Pemodelan Entity Relationship Diagram (ERD) digunakan dalam desain data.

3. Desain antarmuka, memberikan gambaran layout dan struktur menu sistem kepada pengguna.

\section{III.1.3 Implementasi}

Implementasi merupakan proses mengubah desain ke dalam bentuk source code dengan menggunakan bahasa pemrograman. Sistem dibangun dengan menggunakan bahas pemrograman web. Bahasa pemrograman yang digunakan yaitu HTML, CSS, PHP, Javascipt, dan SQL.

\section{III.1.4 Pengujian}

Pengujian yang dilakukan pada penelitian ini yaitu:

1. Pengujian black box, dilakukan kepada pengurus masjid dan pegawai Kemenag untuk memastikan fungisonal sistem berjalan sesuai dengan kebutuhan.

2. Pengujian usability, dilakukan kepada pengurus masjid, pegawai Kemenag dan masyarakat dengan tujuan untuk mengukur tingkat kemudahan sistem. Penilaian usability menggunakan kuisioner SUS.

\section{Hasil dan PEMbahasan}

\section{IV.1 Analisis Kebutuhan}

Sistem informasi profil masjid memiliki 2 level user, yaitu Admin (Kemenag), Operator Masjid (Pengurus Masjid). Interaksi antara user dan sistem dapat dilihat pada Gambar 3.

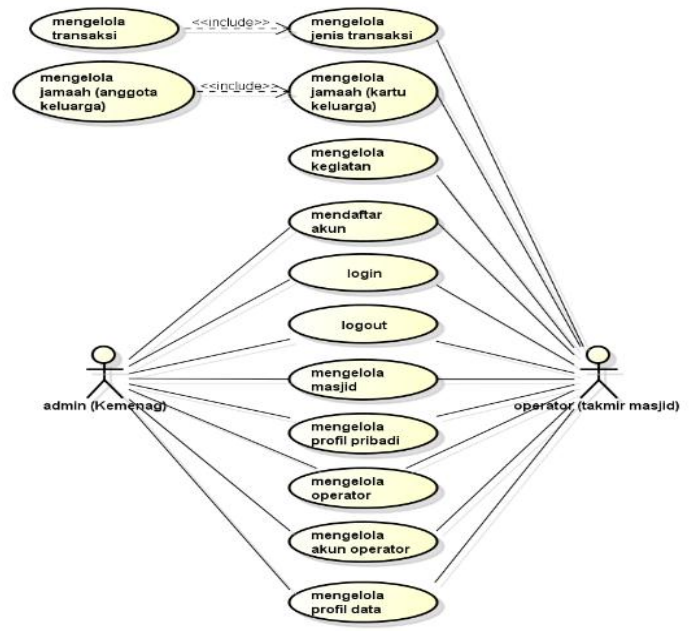

Gambar 3. Use case diagram

\section{IV.2 Desain Sistem}

1. Registrasi masjid

Pengurus masjid dapat melakukan registrasi pada sistem. Kemudian admin akan melakukan verifikasi terhadap data registrasi. Diagram aktivitas registrasi masjid dapat dilihat pada Gambar 4. 


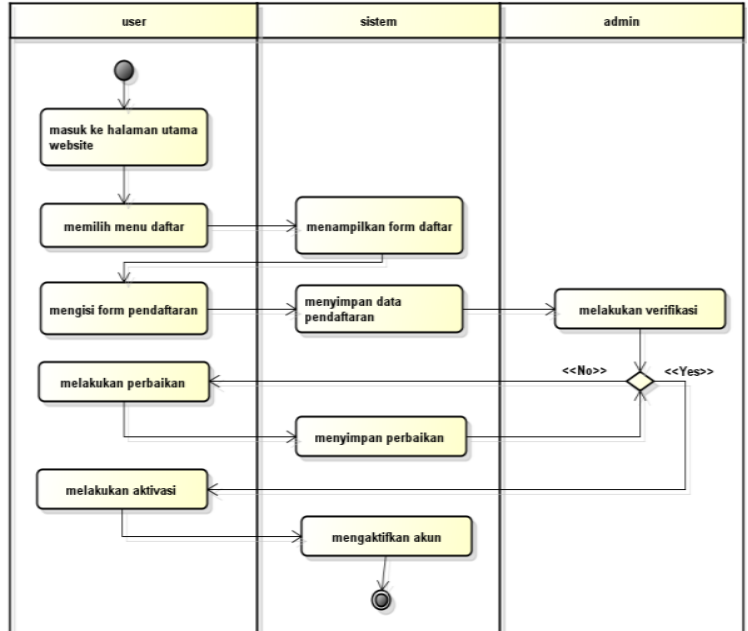

Gambar 4. Diagram aktivitas registrasi masjid

\section{Pendataan Jamaah}

Pengurus masjid dapat melakukan pendataan jamaah pada sistem. Diagram aktivitas pendataan jamaah dapat dilihat pada Gambar 5.

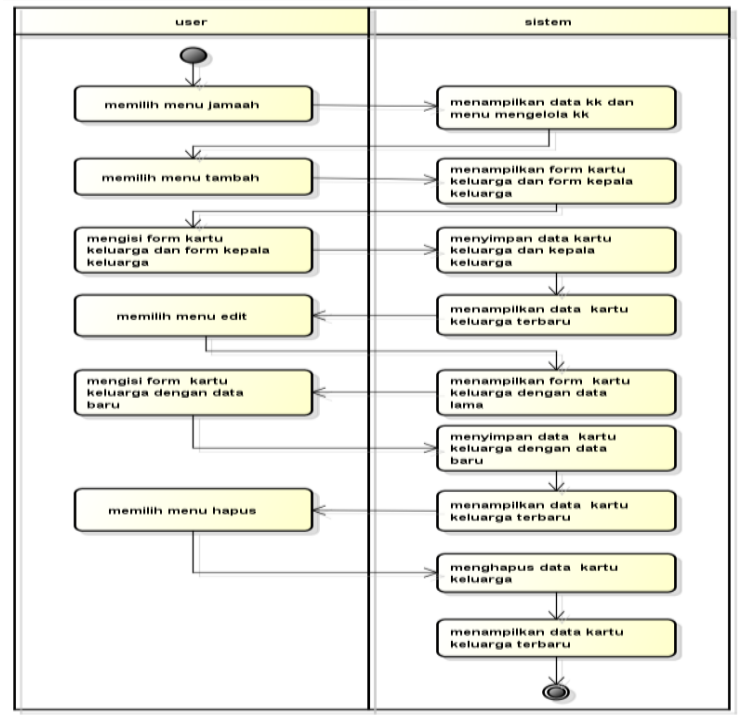

Gambar 5. Diagram aktivitas pendataan jamaah

\section{Pengelolaan Keuangan}

Pengurus masjid dapat melakukan pengelolaan keuangan masjid. Diagram aktivitas pengelolaan keuangan dapat dilihat pada Gambar 6.

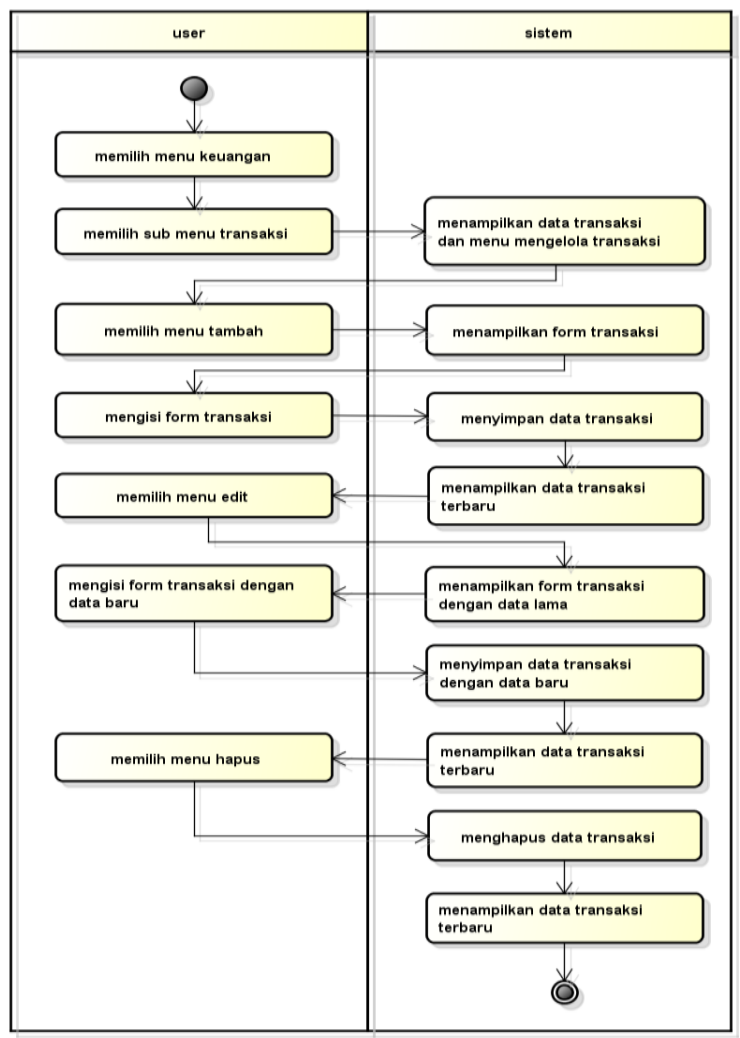

Gambar 6. Diagram aktivitas pengelolaan keuangan

\section{Pengelolaan Kegiatan}

Pengurus masjid dapat melakukan pengelolaan kegiatan yang akan diselenggarakan masjid. Diagram aktivitas pengelolaan kegiatan dapat dilihat pada Gambar 7. 


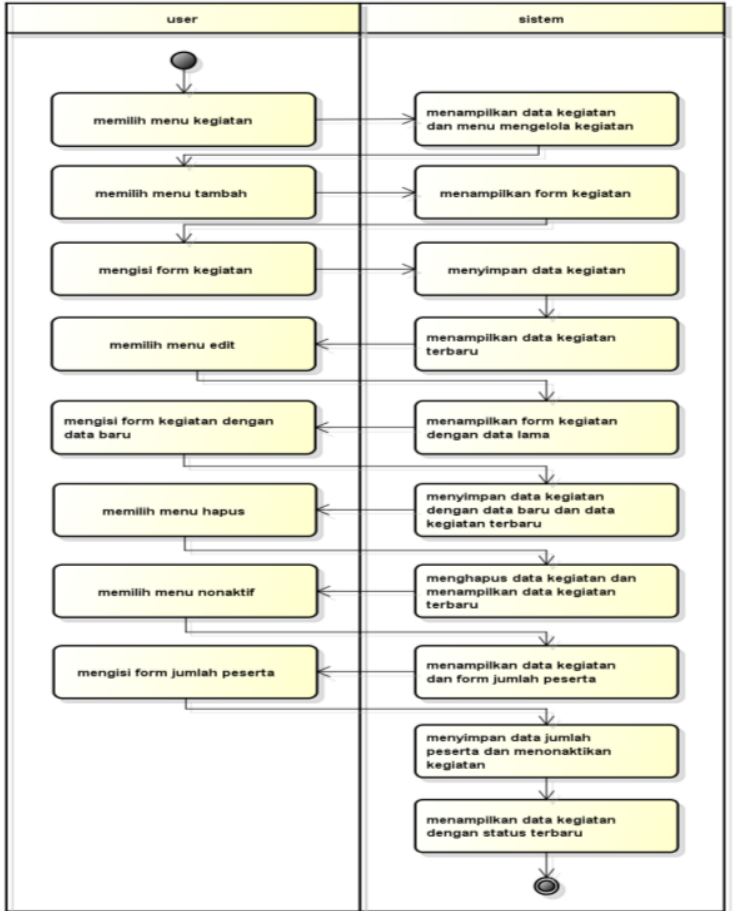

Gambar 7. Diagram aktivitas pengelolaan kegiatan

\section{Profil Masjid}

Profil masjid terdiri dari profil jamaah, profil kegiatan dan profil keuangan. Diagram aktivitas profil data dapat dilihat pada Gambar 8 .

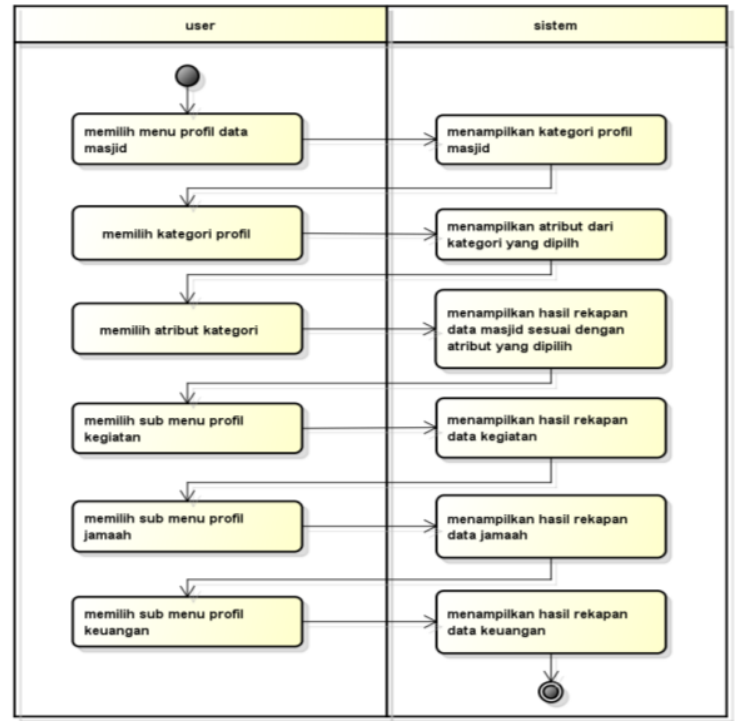

Gambar 8. Diagram aktivitas profil masjid

\section{IV.3 Desain Data}

Pada ERD terdapat 7 (tujuh) entitas, yaitu masjid, user, kegiatan, kartu keluarga, anggota keluarga, jenis transaksi dan transaksi. Terdapat 6 relasi yang menghubungkan antar entitas yaitu user mengelola masjid, masjid menjadwalkan kegiatan, masjid mempunyai jenis transaksi, jenis transaksi mempuyai transaksi, masjid mencatat kartu keluarga, anggota keluarga mempunyai kartu keluarga. ERD dapat dilihat pada Gambar 9.

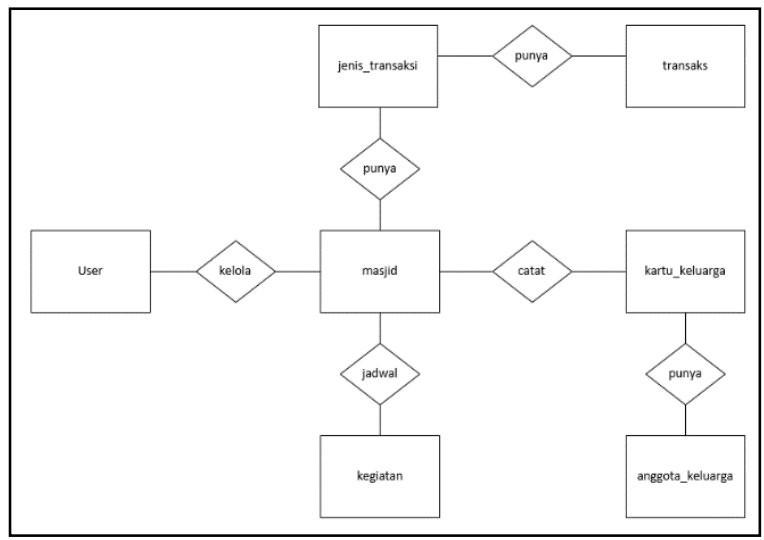

Gambar 9. ERD

\section{IV.4 Desain Antarmuka}

Struktur menu merupakan bagian dari desain antarmuka. Struktur menu terbagi menjadi 2 yaitu struktur menu admin dan struktur menu operator.

1. Struktur menu admin, merupakan tata letak dari menu yang dapat digunakan admin. Struktur menu admin dapat dilihat pada Gambar 10.

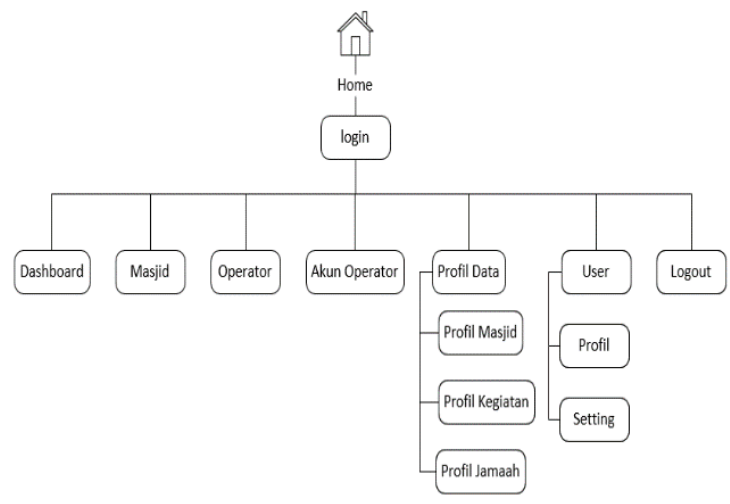

Gambar 10. Sturktur menu admin

Alldy Novryaldy, Tedy Setiadi 
2. Struktur menu operator merupakan tata letak dari menu yang dapat digunakan operator. Struktur menu operator dapat dilihat pada Gambar 11.

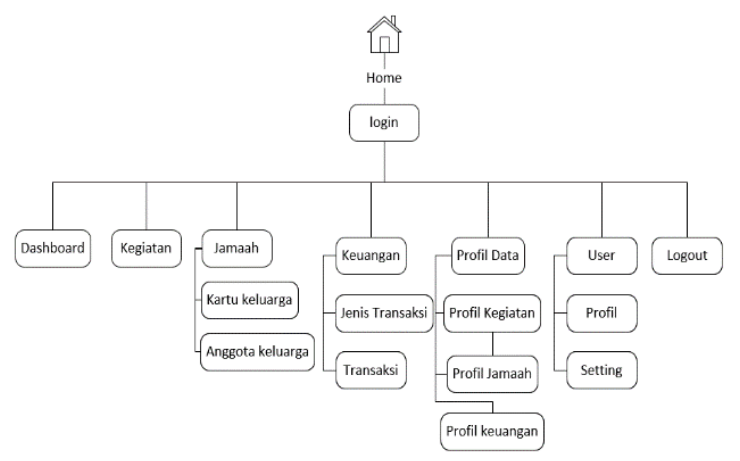

Gambar 11. Struktur menu operator

\section{IV.5 Tampilan Sistem}

\section{Form Registrasi}

Form ini digunakan pengurus masjid untuk melakukan registrasi pada sistem. Form berisi data masjid dan data pengurus masjid yang nantinya akan bertugas sebagai operator masjid. Setelah melakukan registrasi, admin akan melakukan verifikasi terhadap data registrasi. Jika telah diverifikasi, maka pengurus masjid dapat melakukan aktivasi akun untuk dapat login ke sistem. Form registrasi dapat dilihat pada Gambar 12

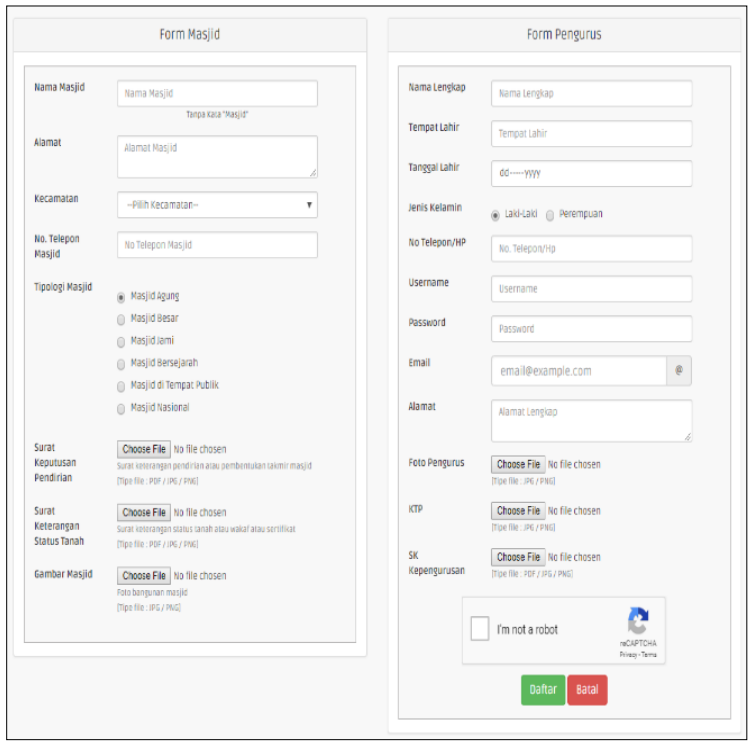

Gambar 12. Form registrasi

\section{Form Jamaah}

Form jamaah digunakan untuk melakuan pendataan jamaah di sekitar masjid. Form jamaah berisi indentitas diri jamaah. Setelah data jamaah tersimpan pada sistem, data akan di olah menjadi informasi profil jamaah. Form jamaah dapat dilihat pada Gambar 13.

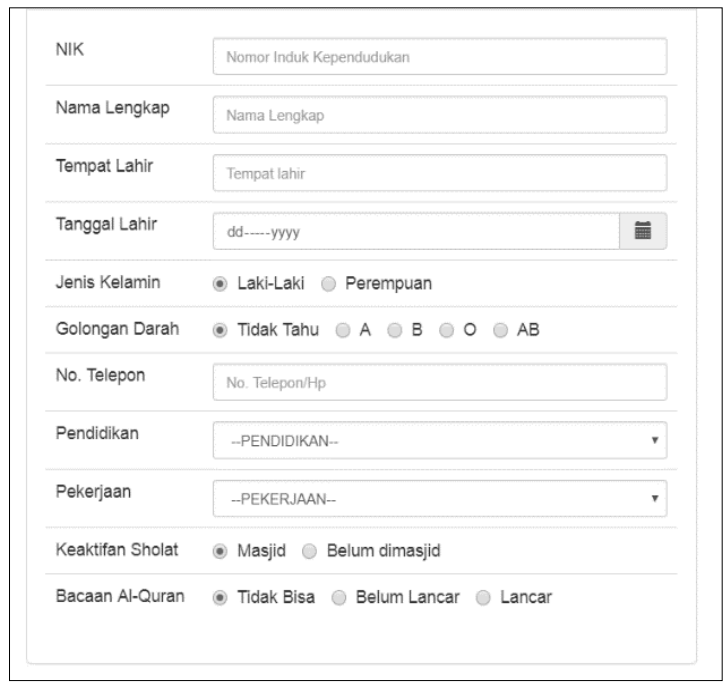

Gambar 13. Form Jamaah

\section{Rekapitulasi Masjid}

Profil masjid akan menampilkan informasi rekapitulasi data masjid seperti berdasarkan tipologi masjid dan kecamatan. Sebagai contoh, diambil dari 31 data masjid berasal dari beberapa kecamatan di Kota Yogyakarta. Kecamatan Umbulharjo memiliki jumlah masjid paling banyak yaitu 9 masjid dan Kecamatan Kotagede memiliki jumlah masjid paling sedikit yaitu 6 masjid. Masjid dengan tipologi masjid jami paling banyak berada di Kecamatan Umbulharjo yaitu 5 masjid dan paling sedikit di Kecamatan Kotagede yaitu 1 masjid. Profil masjid dapat dilihat pada Gambar 14. 


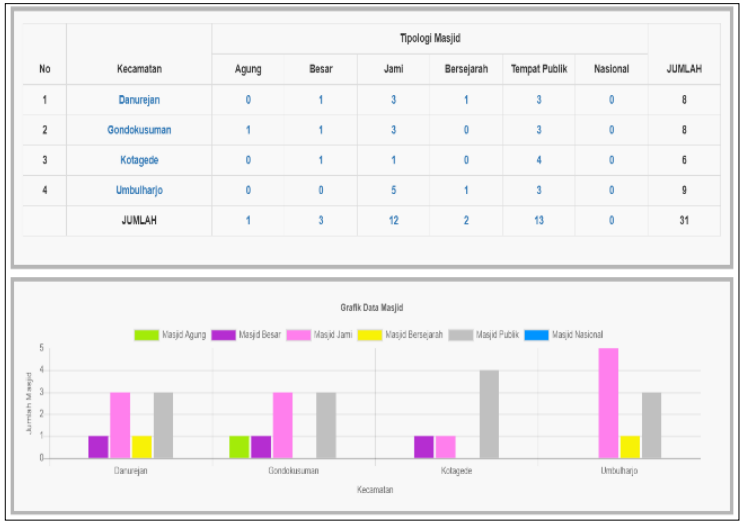

Gambar 14. Rekapitulasi masjid

\section{Profil Jamaah}

Profil jamaah akan menampilkan informasi jamaah seperti, jumlah jamaah, jenis kelamin, kategori usia, keaktifan sholat dan kemampuan baca al-quran. Sebagai contoh, di ambil dari 10 data jamaah terdiri dari 6 berjenis kelamin laki-laki dan 4 berjenis kelamin perempuan. 5 jamaah berada di kategori remaja dan lainya di kategori dewasa. 3 jamaah aktif melaksanakan sholat di masjid dan lainya belum aktif melaksanakan sholat dimasjid. Kemampuan membaca al-quran dari setiap jamaah yaitu 1 jamaah tidak bisa, 4 belum lancer dan 5 lancar membaca al-quran. Profil jamaah dapat dilihat pada Gambar 15.

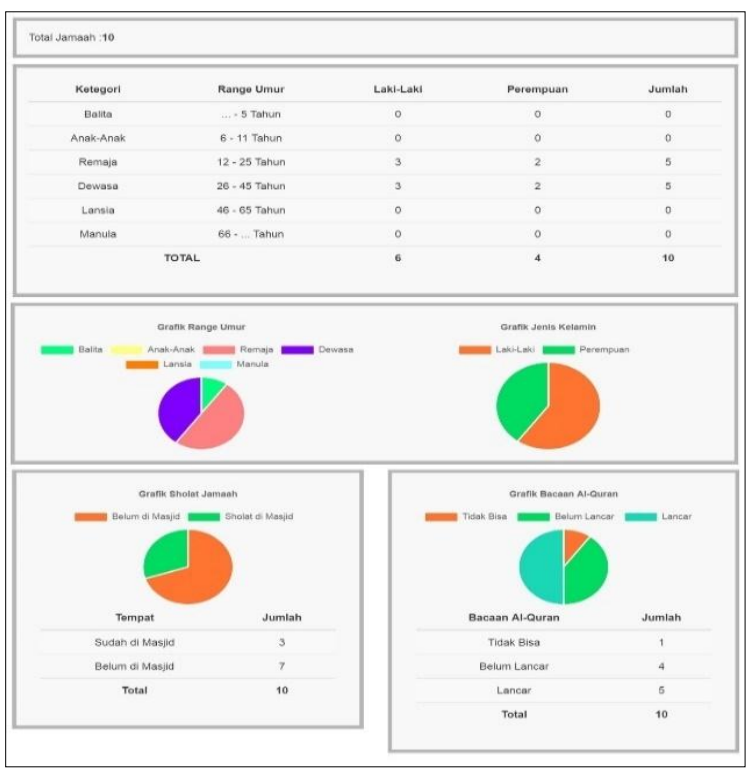

Gambar 15. Profil jamaah

\section{Profil Keuangan}

Profil keuangan akan menampilkan informasi keuangan masjid seperti, total saldo, jenis pemasukan dan pengeluaran, rekapitulasi dana pemasukan dan pengeluaran pada periode tertentu. Sebagai contoh, diambil data keuangan dari bulan oktober sampai desember 2018. Pemasukan terbesar terjadi pada bulan November sebesar Rp. 23.413.500 dan terkecil terjadi pada bulan Desember sebesar Rp. 9.550.000. Pengeluaran terbesar terjadi pada bulan Desember sebesar Rp. 10.225.861 dan terkecil terjadi pada bulan Oktober Rp. 4.353.205. Informasi ini berguna bagi pengurus masjid untuk melihat pertumbuhan keuangan masjid. Profil keuangan dapat dilihat pada Gambar 16.

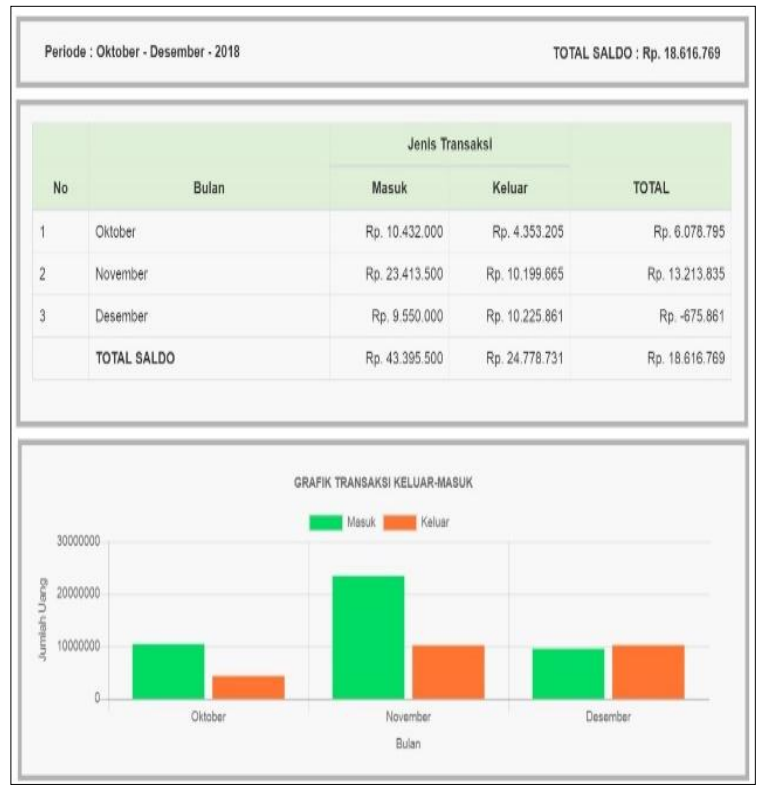

Gambar 16. Profil keuangan

\section{Publikasi Jadwal Kegiatan}

Publikasi jadwal kegiatan yang akan diselenggarakan oleh seluruh masjid yang telah melakukan registrasi pada sistem. infromasi kegiatan dikelompokkan berdasarkan bulan. Sebagai contoh, pada bulan januari 2019 terdapat 8 agenda kegiatan yang akan diselenggarakan masjid. Tampilan informasi kegiatan dapat dilihat pada Gambar 17. 


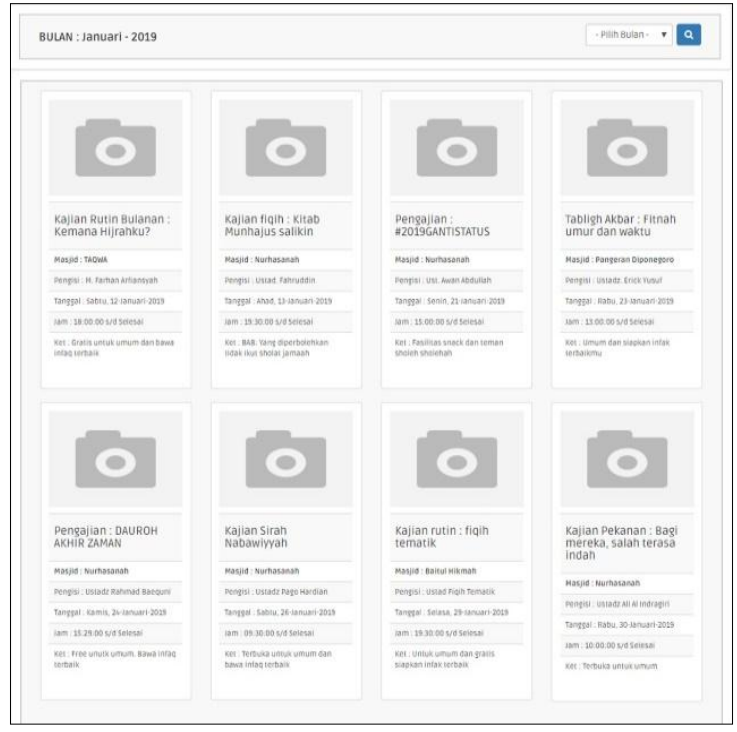

Gambar 17. Publikasi jadwal kegiatan

\section{IV.6 Pengujian}

\section{Pengujian Black Box}

Pengujian black box dilakukan oleh 2 orang yang terdiri dari 1 pegawai Kementerian Agama dan 1 pengurus masjid. Pengujian black box dilakukan pada 2 bagian halaman yaitu halaman admin dan halaman operator. Hasil pengujian black box halaman admin dapat dilihat pada Tabel 1 dan hasil pengujian black box halaman operator dapat dilihat pada Tabel 2.

Tabel 1. Hasil pengujian black box halaman admin

\begin{tabular}{clc}
\hline \hline No & \multicolumn{1}{c}{ Nama } & Hasil \\
\hline \hline 1. & Login & $\sqrt{ }$ \\
2. & Daftar akun admin & $\sqrt{ }$ \\
3. & Tambah masjid & $\sqrt{ }$ \\
4. & Edit masjid & $\sqrt{ }$ \\
5. & Edit operator & $\sqrt{ }$ \\
6. & Konfirmasi akun & $\sqrt{ }$ \\
7. & Nonaktifkan akun & $\sqrt{ }$ \\
8. & Hapus akun & $\sqrt{ }$ \\
9. & Profil masjid & $\sqrt{ }$ \\
10. & Logout & $\sqrt{ }$ \\
\hline \hline
\end{tabular}

Tabel 2. Hasil pengujian black box halaman operator

\begin{tabular}{clc}
\hline \hline No & \multicolumn{1}{c}{ Nama } & Hasil \\
\hline \hline 1. & Daftar akun & $\sqrt{ }$ \\
2. & Tambah kegiatan & $\sqrt{ }$ \\
3. & Edit kegiatan & $\sqrt{ }$ \\
4. & Hapus kegiatan & $\sqrt{ }$ \\
5. & Nonaktifkan kegiatan & $\sqrt{ }$ \\
6. & Tambah kartu keluarga & $\sqrt{ }$ \\
7. & Edit kartu keluarga & $\sqrt{ }$ \\
8. & Hapus kartu keluarga & $\sqrt{ }$ \\
9. & Tambah anggota keluarga & $\sqrt{ }$ \\
10. & Edit anggota keluarga & $\sqrt{ }$ \\
11. & Hapus anggota keluarga & $\sqrt{ }$ \\
12. & Tambah jenis transaksi & $\sqrt{ }$ \\
13. & Edit jenis transaksi & $\sqrt{ }$ \\
14. & Hapus jenis transaksi & $\sqrt{ }$ \\
15. & Tambah transaksi & $\sqrt{ }$ \\
16. & Edit transaksi & $\sqrt{ }$ \\
17. & Hapus transaksi & $\sqrt{ }$ \\
18. & Profil kegiatan & $\sqrt{ }$ \\
19. & Profil jamaah & $\sqrt{ }$ \\
20. & Profil keuangan & \\
\hline \hline
\end{tabular}

Berdasarkan hasil pengujian black box pada Tabel 1 dan Tabel 2, diperoleh hasil sukses sebanyak 30 dan hasil gagal sebanyak 0. Hasil persentase didapatkan masing-masing sebagai berikut:

$$
\begin{aligned}
& \text { Sukses }=\frac{30}{30} \times 100=100 \% \\
& \text { Gagal }=\frac{0}{30} \times 100=0 \%
\end{aligned}
$$

Dapat disimpulkan bahwa semua fungsional yang terdapat pada sistem berjalan sesuai dengan kebutuhan.

\section{Pengujian Usability}

Pengujian usability menggunakan kuisioner SUS dilakukan oleh 10 orang yang terdiri dari 1 pegawai Kemenag, 5 pengurus masjid dan 4 mahasiswa. Hasil rekapitulasi pengujian usability dapat dilihat pada Tabel 3. 
Tabel 3. Hasil rekapitulasi pengujian usability kuisioner SUS

\begin{tabular}{cccccccccccc}
\hline \hline Responden & $\mathbf{1}$ & $\mathbf{2}$ & $\mathbf{3}$ & $\mathbf{4}$ & $\mathbf{5}$ & $\mathbf{6}$ & $\mathbf{7}$ & $\mathbf{8}$ & $\mathbf{9}$ & $\mathbf{1 0}$ & Skor \\
\hline \hline 1 & 5 & 2 & 4 & 2 & 5 & 2 & 4 & 1 & 4 & 4 & 77.5 \\
2 & 5 & 2 & 5 & 2 & 4 & 2 & 5 & 2 & 5 & 2 & 85 \\
3 & 4 & 2 & 4 & 2 & 4 & 1 & 4 & 2 & 5 & 2 & 80 \\
4 & 5 & 1 & 5 & 2 & 5 & 1 & 5 & 1 & 5 & 2 & 95 \\
5 & 4 & 2 & 4 & 2 & 5 & 1 & 4 & 2 & 5 & 2 & 82.5 \\
6 & 5 & 1 & 5 & 2 & 5 & 1 & 5 & 1 & 5 & 1 & 97.5 \\
7 & 5 & 2 & 5 & 2 & 4 & 2 & 5 & 2 & 5 & 2 & 85 \\
8 & 5 & 1 & 5 & 2 & 4 & 2 & 5 & 1 & 5 & 2 & 90 \\
9 & 4 & 2 & 4 & 2 & 3 & 2 & 5 & 1 & 5 & 2 & 20 \\
10 & 4 & 2 & 5 & 1 & 4 & 1 & 5 & 1 & 5 & 1 & 92.5 \\
Rata-rata & 4.6 & 1.7 & 4.6 & 1.9 & 4.3 & 1.5 & 4.7 & 1.4 & 4.9 & 2 & 86.5 \\
\hline \hline
\end{tabular}

Hasil pengujian usability didapatkan nilai skor SUS sebesar 86.5. Dilakukan pengukuran nilai skor SUS dengan menggunakan skala konversi skor SUS didapatkan bahwa sistem mempunyai tingkat usability yang excellent.

Berdasarkan kedua pengujian yang telah dilakukan, maka dapat disimpulkan bahwa sistem dapat berjalan sesuai dengan kebutuhan dan diterima oleh pengguna.

\section{KESIMPULAN DAN SARAN}

Berdasarkan hasil dan pembahasan yang telah diuraikan, dapat disimpulkan bahwa:

1. Telah dibangun sebuah sistem yang dapat menyajikan informasi profil masjid, kegiatan, jamaah dan keuangan masjid.

2. Hasil pengujian black box mendapatkan nilai $100 \%$. Hasil pengujian usability dengan menggunakan kuisioner SUS mendapatkan nilai 86,5. Berdasarkan kedua pengujian yang telah dilakukan, maka dapat disimpulkan bahwa sistem dapat berjalan sesuai dengan kebutuhan dan diterima oleh pengguna.
3. Perlu dikembangkan fitur yang memungkinkan admin (kemenag) untuk berkomunikasi dengan operator (pengurus masjid) melalui sistem.

4. Sistem belum dapat menangani masalah pendataan jamaah yang telah melaksanakan haji, qurban, dan zakat. Perlu dikembangkan pendataan tersebut agar masjid mendapatkan gambaran jamaah yang lebih lengkap.

\section{REFERENSI}

Ardiansyah, \& Ghazali, M. I. (2016). Pengujian Usability User Interface dan User Experience Aplikasi E-Reader Skripsi Berbasis Hypertext. Jurnal Ilmiah Teknologi Informasi Terapan, II(3). https://doi.org/10.15408/jti.v10i2.6824

Buana, C. S., Susanto, T., \& Suhandiah, S. (2016). Rancang Bangun Aplikasi Informasi Kegiatan Masjid Berbasis Web Pada Masjid Tanwir Surabaya. Jurnal Sistem Informasi \& Komputer Akuntansi, 5(7).

Busthomi, A. O. (2017). Bisnis dan Praktik Sosial: AtTaqwa Bisnis Center, Primkopjamas, dan Laziswa Masjid At-Taqwa Cirebon. Jurnal 
Penelitian Hukum Ekonomi Islam, 2(1), 24-33.

Haq, J. A. A., \& Dewi, M. K. (2013). Praktik Manajemen Keuangan Masjid dan Potensi Dana Masjid ( Studi Kasus Pada Beberapa Masjid di Kota Bogor ).

Iwan, A., \& Herdiana, D. (2018). Optimalisasi Pemberdayaan Masyarakat Berbasis Masjid, 12(April), 82-98. https://doi.org/10.15575/idajhs.v12i.2

Laudon, K. C., \& Laudon, J. P. (2014). Sistem Informasi Manajemen: Mengelola Perushaan Digital (13th ed.). Jakarta: Salemba Empat.

Muharam, A. (2018). 5 Keunggulan Aplikasi Web. Retrieved February 11, 2019, from https://techarea.co.id/keuntungan-aplikasimobile-dari-website/

Pudjoatmodjo, B., \& Wijaya, R. (2016). Tes Kegunaan (Usability Testing) Pada Aplikasi Kepegawaian Dengan Menggunakan System Usability Scale. Seminar Nasional Teknologi Informasi Dan Multimedia 2016, (2302-3805), 37-42.

Qadaruddin, M., Nurkidam, A., \& Firman. (2016). Peran Dakwah Masjid dalam Peningkatan Kualitas Hidup Masyarakat, 10(2), 222-239.

Sub Direktorat Kemasjidan. (2014). Buku Panduan Sistem Informasi Masjid (SIMAS).

Suherman, E. (2012). Manajeman Masjid Kiat Sukses Meningkatkan Kualitas SDM Melalui Optimaslisasi Kegiatan Umat Berbasis Pendidikan Berkualias Unggul. Bandung: Alfabeta.

Sukamto, A. R., \& Salahuddin, M. (2016). Rekayasa perangkat Lunak Terstruktur dan Berorientasi Objek. Bandung: Informatika Bandung.

Syaifullah, Priyanto, H., \& Irwansyah, M. A. (2016). Rancang Bangun Aplikasi Sistem Informasi Masjid, Panti Asuhan, dan Pesantren Berbasis Web. Jurnal Sistem Dan Teknologi Informasi, 1(1), 5 .

Wardana, T. I., \& Aribowo, E. (2013). Informasi Manajemen Kegiatan Masjid Studi Kasus : Masjid Jogokariyan Yogyakarta. Jurnal Sarjana Teknik Informatika, 1(1), 119-128.

Welim, Y. Y., \& Sakti, A. R. (2016). Rancang Bangun Sistem Informasi Administrasi Pengelolaan Dana Masjid Pada Yayasan Al-Muhajiriin,
Tangerang. Simetris: Jurnal Teknik Mesin, Elektro Dan Ilmu Komputer, 7(1), 29. https://doi.org/10.24176/simet.v7i1.485

Alldy Novryaldy, Tedy Setiadi 